\section{シリコンホトダイオードによる単色 光の放射束測定}

\section{1 標隼検出器としてのシリコンホトダイオード}

ンリコンホトダイオードは放射測定検出器としての諸 特性がすくれているのて，最近広く利用されるよらに なってきている その主な長所は放射束対光電出力の直 線性がよいこと，比較的感度がよいのて出力测定が容易 なこと, 受光面の感度さらを小さくてきること, 温度に よる感度变化や経時变化が小さいこと, 機械的に丈夫で 取扱いが簡便なことなとである

シリコンホトダイオートのるつこのようなすくれた特 性は, 放射測定の基準となる二次標隼検出器の其倩与人 き条件を注注满足しているのて,ンリコンホトタイオー ドは分光感度を仭定することによって標隼検出器となり 得るといらことかてきる 分光感度の校正された標隼検 出器は分光器から出てくる単色光やレーザ光の放射束を 直接測定するのに特に有用てあるこの場合大別して $2 つ の$ 利用面が考之られる一つは央験に用いた単色放 射束のおよその值（10２0\%程度の正確さ）を知ること

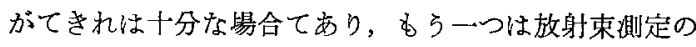
精度が実験結果に直接影響するのててきるだけ正確な測 定（通常は波長に対する相対值を正確に决定すればよい ことが多い）を必要とする場合てある 前者に扣いては 测定器メーカーのつけた校正値をそのまま利用てきるこ とが多いが，後者の場合にはニーザー自身が分光感度の 校正について考慮を払ら必要が生してくるこの問題に ついて後て述へることにする

\section{2 シリコンホトダイオード検出器の具体的な特性}

筆者の一人が可視域に颃ける単色光の放射束测定に用 いた検出器1) は EG \& G 社の 550 型ラジオメータで, $450 \mathrm{~nm}$ から $1000 \mathrm{~nm}$ までの波長域で分光感度が注汪 平坦てあり，士5\%の正確さて测定てきると称している ものてあって, ノリコンホトダイオードと干啮フィルタ の組合せからなっているこの測定器の応用面に関する メーカ一側の説明は明瞭さを欠くるのてあったが，特別 に校正を行らことによって可視域の単色光の放射束の精 密測定に有效に利用できることに着目し，種々の特性を 調へると其に分光感度を仭定した まず，380 $\mathrm{nm}$ から $1200 \mathrm{~nm}$ にわたって相対分光感度を測定してみると Fig 1 のような結果が得られたこの図から指定され た波長域に持ける分光感度のばらつきは土6\%程度てあ るとい学るな招，絶対感度についてもレーザー光源及

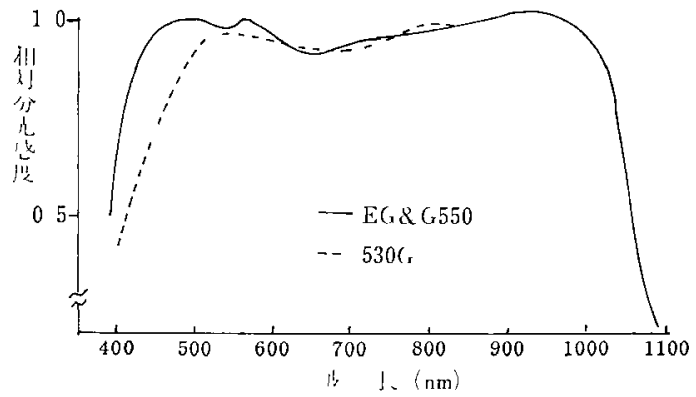

Fig 1 相対分光感度の測定例

ひ分光放射照度標準光源を用いて再校正した結果と実験 䛊美以内て一致していることか確認された

文献（2）に扣いて斎藤はシリコンホトダイオードの諸 特性について広範な测定を行っているが、ンリコンホト ダイオード単体ても分光感度特性の平坦なる（波長域 は若干狭くなる）があることを報告している 皇の素子 は SHARP $530 \mathrm{G} \tau$ ，その相対分光感度曲線を Fig 1 に伊せて示してある 上述の 2 つ倹出器ては一つの校 正値を特定の波長域内て利用てきる利点かあるが，この 場合は測定の正確さが若干犠牲になることはやむを得な い.

次に, 標準検出器として重要な2，3の性質について も調へてみた 受光面の場所による感度むらは前述の 550 型については $01 \%$ の精度て感度むらのないことが 確認され，また，530 G の場合は受光面の大部分で感度 のばらつきは $1 \%$ 以内, 特定の直線上の部分 (電極) て 約 $9 \%$ の感度むらとなって和り, 十分な害用性をもって いる 放射束対光電出力の直線性は良好て，550 型の場 合 $1999 \times 10^{-3} \sim 1999 \times 10^{3} \mu \mathrm{W} / \mathrm{cm}^{2}$ の範囲内* て直線 性からのはずれは $1 \%$ 以下，530G の場合光電流 $43 \times$ $10^{-5} \sim 35 \times 10^{-9} \mathrm{~A}$ の範囲て值線性からのはずれは OP アノプ (100902) を含めて 1 1\% 以下てあり，光電流範 用を $34 \times 10^{-7} \sim 34 \times 10^{-9} \mathrm{~A}$ 限れば直線性からのは ずれは $01 \%$ 以内に収まるな⿰、ンリコンホトダイオ ード UDT 500 UV を直線性よく使用するにはバイアス をかけることが必要なのて注意を要する

感度の温度による変化も一般に小さく, $530 \mathrm{G}$ の場合 温度を $10^{\circ} \mathrm{C}$ から $30^{\circ} \mathrm{C}$ まて変光たときの $400 \sim 800 \mathrm{~nm}$ の波長域に扩る感度変化は $\pm 1 \%$ 程度となっている さらに文献（2）ては太陽光て照射しなから感度の経時変 化を調べているが，太陽光に30時間さらした結果分光感

*メ一カーの技術者の話によると最高レンシの10倍ま では使用可能てあるとのことてある. 
度はほとんと変化していないと報告している

以上ノリコンホトダイオートを放射湘定に使用するに 当って注意すへき諸特性について，2つの検出器を例に とって述へた 残された問題は，特に正確な放射束例定 を必要とする場合に独自に分光感度を仭定することてあ な

\section{3 分光感度の决定}

最も一般的な相対分光感度の測定法は，分光器を用い て単色光を取出し，例党ば F1g 2 のよらな光学系（熱 型検出器と被側定検出器の受光面の形の組合せ飞よって 適当な光学系を選ぶ）方を用いて熱型検出器と被测定検 出器に交互にあてて，それそれの出力を各波長ごとに測 定し, 蠜型検出器の出力に対する比として求める方法て ある 注意すへき点俩方の検出器に同じ放射束をあて ること，放射束のあて方は実際に利用する場合と同じ条 件にすることてある たたし，受光面に感度さらのない 場合は任意の場所にあててるよい 相対分光感度か仭定 されれば，あるつの佊長て絶詨感度を定めることに よって全波長域の分光感度が求まるこの光源としては レーザーが適して出り，感度既知のサーモパイルまたは ボロメータと比較測定する

相対分光感度（ぬたは分光感度）の測定にあたって推 将したいのはレーザーの利用てある レーザーを利用す る分光感度即定ては分光器やそれに付属する光学系を必 要とせず，しかも放射束が大さいのて感度の低い熱型検 出器による湘定か容易になるといら利占をもっている るらろん，枝長可変レーザーを用いない限り校正でさる 波長には限りがあるが，レーザーの放射束則定に利用す るには問題かないし，数点の皮長について正確な分光感 度を决めておくことは分光器を用いる相詨分光感度测定 にとっても大いに参考になる

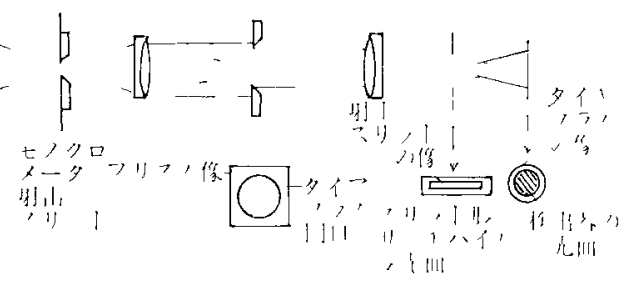

F1g 2 相対分光感度測定光学系の一例
レーザー光の放射束测定については既にこの闌で述へ られているが，一般的な放射束测定について若丁の補 足をして扰をたい单色放射束側定の基隼となるのは絶 刘放射的てあるか，これを基华として校正された標隼検 出器か一般に用いられる一力, 絁対放射可を基準とし て二次標隼光源が校正されているこれは安定な光源か ら特定の距離にある点の放射昭度を絶対放射計て校正し たものて，この位置に被湘定検出器をおけば放射喝度当 りの感度を目盛づけなることかてきる また，同じ位置 に面積既知のタイアフラムを执きこれを通過した放射 束を検出器にあてれば放射束当りの感度が目盛づけされ るこの放射照度標隼電球を棈度よく利用てきるのは佊 辰 $15 \mu \mathrm{m}$ 位召て分炎感度の平坦な埶型検出器に限られ るこれは㫣球ハルプからの放射が約 $10 \%$ 含まれること による

放射昭度標準電球と同しよらな考方方で太陽直射光を 天然の標隼光源として利用し, 熱型検出器の感度の概略 值を决定することかできる 検出器の受光面を太陽に正 奶させ，天空光を庶るための円简を取付ければ，决啨时 太陽高度 $30^{\circ}$ のとさの放射昭度怔約 $70 \mathrm{~mW} / \mathrm{cm}^{2}$, 太 陽高度 $90^{\circ}$ て約 $80 \mathrm{~mW} / \mathrm{cm}^{2}$ となるこの場合は熱型 受光器の分光感度特性は $03 \sim 3 \mu \mathrm{m}$ の波長域て平坦で あればょいたたし，高い放射炤度を与兄てょいものに 限る

熱型検出器の感度を校正するるら一つの便法は测光標 焦を利用する方法てある 一例をあげれば，透明バルブ の高生水銀ランプからの放射を，550 nm より短佊長側 と赤外域とをカトなるフィル夕 (V-O 56+IRQ-80) を通して検出器にあてて出力を測定するこのときの

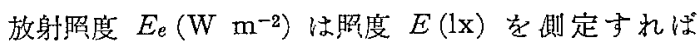
$E /(683 \times 0$ 889) て与克られる ここで，0 889 は 577 $\mathrm{nm}$ と $579 \mathrm{~nm}$ の標隼比視感度の平均值て, 校正の精 度は主として昭度計による湘定の精度に依存する

（電総研 鉿木 守 香取寬二）

\section{文献}

（1）不破汪か，昭和54年度照明学会全国大会 No 70

(2) 斎藤一朗. 電子技術総合研究所研究報告第 803 号

（3）渡会吉昭 昭明学会猚志 58-11，580（1974）

(4) 本田汪か，分光砳究 28-3，159（1979） 